\title{
Foresight of physical-chemical characteristics of apple juice blends appointed to sparkling drink elaboration
}

\author{
Previsão das propriedades físico-químicas de misturas de sucos de maçãs \\ destinadas à elaboração de espumantes
}

\author{
Catherine Valente de CARVALHO $^{1 *}$, Nelci Catarina CHIQUETTO $^{1}$
}

\begin{abstract}
The purpose of this research was to combine the use of the component blend design to the response surface methodology, in order to foresee the effect of ternary apple juice blends (Catarina, Granny Smith and Pink Lady cultivars) on the physical-chemical characteristics of musts appointed to sparkling drink elaboration. Twelve mixes were made (three individual samples, three binary mixes and six ternary mixes), analyzed on the content of total reducing sugars, total titratable acidity and phenolic compounds; and adjusted, respectively, to the linear, quadratic and special cubic models. The results were organized in ternary charts of surface response and, from the overlap of these charts, it was determined a viable region which delimited the range of apple juice compositions that make musts physically and chemically suitable to sparkling drink elaboration. To represent the various possible combinations, the central point of the triangular area of the viable region was calculated and, this point, which represents the proportions of $23.22 \%$ of Catarina, $66.23 \%$ of Granny Smith and $10.55 \%$ of Pink Lady cultivars, was chosen to constitute the formulation of the must to be used in the elaboration of apple sparkling drinks.
\end{abstract}

Keywords: blend; statistical design; must; apple.

\section{Resumo}

O objetivo desta pesquisa foi utilizar o planejamento para misturas de componentes aliado à metodologia de superfície de resposta para prever o efeito da mistura ternária de sucos de maçãs (cultivares Catarina, Granny Smith e Pink Lady) nas características físico-químicas de mostos destinados à elaboração de espumantes. Foram formuladas 12 misturas ( 3 amostras individuais, 3 misturas binárias e 6 ternárias), as quais foram analisadas quanto ao teor de açúcares redutores totais, acidez total titulável e compostos fenólicos e ajustados, respectivamente, aos modelos linear, quadrático e cúbico especial. Os resultados foram organizados em gráficos ternários de superfície de resposta e, a partir da sobreposição destes gráficos, foi determinada uma região viável que delimitou a gama de composições de sucos de maçãs que formulam mostos físico-quimicamente aptos para a elaboração de espumantes. Para representar as diversas combinações possíveis, foi calculado o ponto central da área triangular da região viável e este ponto, que representa as proporções de 23,22\% da cultivar Catarina, 66,23\% da cultivar Granny Smith e 10,55\% da cultivar Pink Lady, foi escolhido para constituir a formulação do mosto a ser utilizado na elaboração de espumantes de maçã. Palavras-chaves: mistura; planejamento estatístico; mosto; maçã.

\section{Introduction}

In Brazil, there is no apple production intended only for industrial use. In Brazilian cider production, only table fruits are used, i.e., apples that have desirable features for in natura consumption but, due to some deformities, were discarded of the trade (WOSIACKI, 2002).

For the sparkling drink elaboration, it is desirable that the must hold a combination of high acidity with high content of phenolic compounds and sugar, besides fruity aroma. This combination of parameters is not achieved in a single apple cultivar, being necessary the use of individual characteristics of each cultivar in blends (JORGE; TREPTOW; ANTUNES, 1998). According to Wosiacki and Nogueira (2005), some cultivars currently used as pollinating have more significant levels of organic acids and phenolic compounds and can be used in processed juice blends to give "body" to the beverages produced.

The most indicated statistical method to a blend elaboration is the component blend design, which adjusts models to represent the response on a surface. The goal of the method is to find a model that describes the physical-chemical characteristics of blends with the smallest error margin possible, when compared to the real results of the experiments. The simplest model of this design is the linear, which tries to explain the behavior of a property only with the results obtained with the utilization of each component individually. Besides this model, the design can be raised to quadratic and special cubic levels. In the former, one must employ the results of the interaction effects between two components, whereas in the latter, the effects of

Recebido para publicação em 28/3/2009

Aceito para publicação em 8/7/2009 (004133)

1 Universidade Estadual de Ponta Grossa - UEPG, Campus Uvaranas, Av. General Carlos Cavalcanti, 4748, CEP 84030-900, Ponta Grossa - PR, Brasil,

E-mail: cvc.alimentos@gmail.com

${ }^{*}$ A quem a correspondência deve ser enviada 
interaction of three compounds must be used (BARROS NETO; SCARMINIO; BRUNS, 2007).

This research had as objective to foresee the physicalchemical characteristics of ternary blends of apple juices using the component blend design with the response surface methodology, where the selection of the cultivars was based on the physical-chemical characteristics that better adapt to the requirements of a must intended to sparkling drink elaboration.

\section{Materials and methods}

\subsection{Raw materials}

Three apple cultivars were selected to the elaboration of the ternary blend design, namely, Catarina, Granny Smith and Pink Lady. The Catarina cultivar was selected because it has a high content of phenolic compounds (377.97 mg. $\mathrm{L}^{-1}$ ) and total reducing sugars (142.86 g.. $\left.\mathrm{L}^{-1}\right)$. The Granny Smith and Pink Lady cultivars were selected for having high acidity (5.52 and 4.70 g.L $\mathrm{L}^{-1}$, respectively). The Pink Lady has fruity aroma as well. All of the cultivars were from the 2007/2008 harvests of the State of Santa Catarina and were provided by the company 'Agrícola Fraiburgo Ltda' (Videira - SC, Brazil).

The selected apples were washed in running water and crushed in a manual processor. The juice obtained was kept frozen $\left(-20^{\circ} \mathrm{C}\right)$ until the time of the analysis

\subsection{Physical-chemical analysis}

The total reducing sugars analysis was performed by the Somogyi-Nelson colorimetric method, and the result was expressed in g.L. $\mathrm{L}^{-1}$ (TANNER; BRUNNER, 1985). For the determination of total titratable acidity, the technique of the 'Instituto Adolfo Lutz' was used, and the result was expressed as malic acid in g.L $\mathrm{L}^{-1}$ (INSTITUTO..., 2008). The phenolic compounds were analyzed colorimetrically with the reagent Folin-Ciocalteau and expressed in mg. $\mathrm{L}^{-1}$ of catechin (SINGLETON; ORTHOFER; LAMUELA-RAVENTOS, 1999).

\subsection{Components blend design}

Initially, the linear models for all properties considered were tested and these models were adjusted to more complex ones (quadratic and especial cubic) as a need to make them more meaningful.

For the determination of the equation coefficients, 12 experimental essays were used, where the blends proportions were defined by use of the components blend design, as Table 1 . The blends were made with the juices of Catarina, Granny Smith and Pink Lady cultivars, represented by $\mathrm{x} 1, \mathrm{x} 2$ and $\mathrm{x} 3$, respectively. The sum of the percentages of these samples met the restriction mentioned by Bruns, Scarminio and Barros Neto (2001) where the sum should be equal to 1 .

The response variables used in the design were: total reducing sugars (TRS), total titratable acidity (TTA) and phenolic compounds (PC). The results were organized in charts and analyzed by the response surface methodology.

\section{Results and discussion}

Figure 1 shows the values of total reducing sugars, total acidity and phenolic compounds for the 12 assays made, besides the representative point of the viable region (Intersection Point - IP).

Analyzing the chart (Figure 1), one can observe that the cultivar Catarina (assay 1) shows up more clearly, with higher content of total reducing sugars, than the other cultivars: Granny Smith and Pink Lady (assays 2 and 3, respectively), which have high acidity, in agreement with the reasons given for their selections.

According to Jorge, Treptow and Antunes (1998), cultivars with high degree of aroma generally have low acidity, so it must be mixed with higher acidity cultivars. The Pink Lady cultivar was selected for having more fruity aroma, in addition to its relatively high acidity $\left(4.70\right.$ g.L $\left.\mathrm{L}^{-1}\right)$.

From the results obtained for the different compositions, it was possible to generate regression models at different levels, correlating the proportions of the apples juices to the results of the parameters studied. The models for each parameter were chosen from the validation of these models in a significance level of $95 \%$. For each property, different regression models were generate and evaluated by variance analysis (ANOVA). Table 2 shows the statistic parameters used to analyze the linear, quadratic and special cubic models for all variables.

To evaluate whether the models had a significant regression in the confidence level of $95 \%$, the $\mathrm{F}$ values obtained (related to regression and to the models fit) were compared to the respective $\mathrm{F}$ tabulated values. The $\mathrm{R}^{2}$ value, which represents the variation explained by the model, had to be as close as possible to the maximum explainable value.

The residue charts of each model were seen as random, and, for better representation of data, the chart should display randomly. These parameters were observed in all models of each variable and the model that was significant for all parameters

Table 1. Proportions of each cultivar in the elaboration of 12 experimental assays, by use of the components blend design.

\begin{tabular}{rcccc}
\hline Essays & Description & \multicolumn{3}{c}{ Proportions of each cultivar in the assays } \\
\cline { 3 - 5 } & & $\begin{array}{c}\text { Catarina } \\
(\mathrm{x} 1)\end{array}$ & $\begin{array}{c}\text { Granny Smith } \\
(\mathrm{x} 2)\end{array}$ & $\begin{array}{c}\text { Pink Lady } \\
(\mathrm{x} 3)\end{array}$ \\
\hline 1 & Individual & 1 & 0 & 0 \\
2 & samples & 0 & 1 & 0 \\
3 & & 0 & 0 & 1 \\
\hline 4 & Binary & $1 / 2$ & $1 / 2$ & 0 \\
5 & mixes & $1 / 2$ & 0 & $1 / 2$ \\
6 & & 0 & $1 / 2$ & $1 / 2$ \\
\hline 7 & Ternary & $1 / 3$ & $1 / 3$ & $1 / 3$ \\
8 & mixes & $1 / 3$ & $1 / 3$ & $1 / 3$ \\
9 & & $1 / 3$ & $1 / 3$ & $1 / 3$ \\
10 & & $2 / 3$ & $1 / 6$ & $1 / 6$ \\
11 & & $1 / 6$ & $2 / 3$ & $1 / 6$ \\
12 & & $1 / 6$ & $1 / 6$ & $2 / 3$ \\
\hline
\end{tabular}




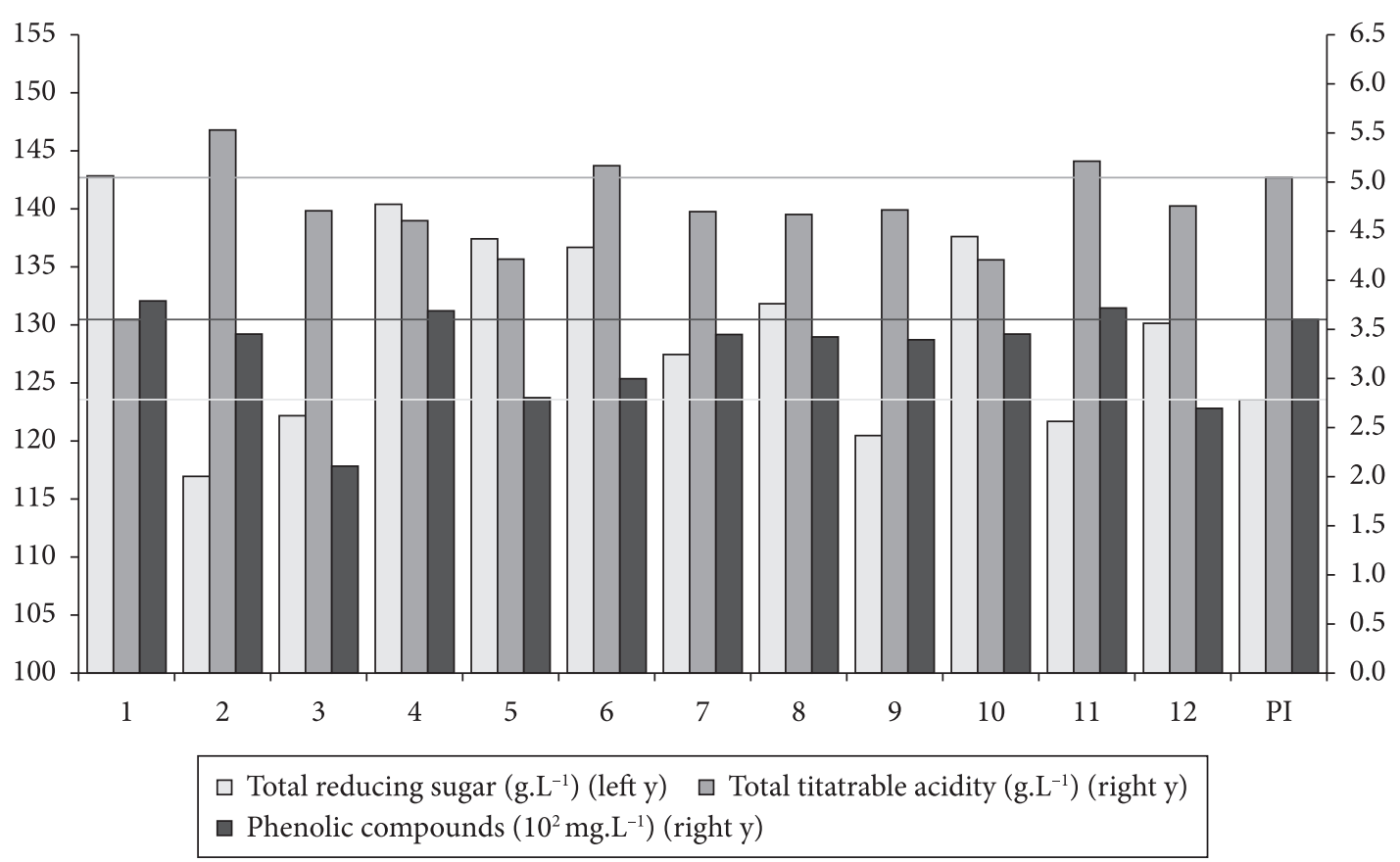

Figure 1. Average values of TRS, TTA and PC to the different assays established by the components blend design, applied to the three apples cultivars (Catarina, Granny Smith and Pink Lady). Label: TRS - total reducing sugars (10 g. $\left.\mathrm{L}^{-1}\right)$ on the left y axis; TTA - total titratable acidity (g. $\mathrm{L}^{-1}$ in malic acid) on the right y axis; PC - phenolic compounds $\left(10^{2} \mathrm{mg} . \mathrm{L}^{-1}\right)$ on the right $\mathrm{y}$ axis. Values relative to all assays made (1 to 12$)$ and for the representative point of the viable region (intersection point - IP).

Table 2. Variance analysis (ANOVA) of regression models made to the variables total reducing sugar, total titratable acidity and phenolic compounds.

\begin{tabular}{clcccccc}
\hline Variables & \multicolumn{1}{c}{ Model } & Test F & $\begin{array}{c}\text { F tabulated } \\
(5 \%)\end{array}$ & $\begin{array}{c}\text { Test F to } \\
\text { lack of fit }\end{array}$ & $\begin{array}{c}\mathrm{F}_{\text {lf }} \text { tabulated } \\
(5 \%)\end{array}$ & $\begin{array}{c}\mathrm{R}^{2} \text { explained } \\
\text { variation }\end{array}$ & $\begin{array}{c}\mathrm{R}_{\text {ex }}^{2} \text { explainable } \\
\text { varitation }\end{array}$ \\
\hline Total reducing sugar & Linear & $13.684^{\mathrm{a}}$ & 5.140 & $0.273^{\mathrm{d}}$ & 19.250 & 0.8202 \\
& Quadratic & $1.432^{\mathrm{b}}$ & 4.390 & $7.002^{\mathrm{d}}$ & 19.250 & 0.8837 \\
& Special cubic & $5.050^{\mathrm{b}}$ & 4.950 & $0.427^{\mathrm{d}}$ & 19.160 & 0.5441 & 0.9696 \\
\multirow{5}{*}{ Total titratable acidity } & Linear & $99.281^{\mathrm{a}}$ & 5.140 & $36.208^{\mathrm{c}}$ & 19.250 & 0.9707 & 0.9136 \\
& Quadratic & $238.595^{\mathrm{a}}$ & 4.390 & $6.694^{\mathrm{d}}$ & 19.250 & 0.9950 & 0.9996 \\
& Special cubic & $225.112^{\mathrm{a}}$ & 4.950 & $6.398^{\mathrm{d}}$ & 19.160 & 0.9963 & 0.9997 \\
Phenolic compound & Linear & $13.980^{\mathrm{a}}$ & 5.140 & $161.903^{\mathrm{c}}$ & 19.250 & 0.8233 & 0.9995 \\
& Quadratic & $11.992^{\mathrm{a}}$ & 4.390 & $85.409^{\mathrm{c}}$ & 19.250 & 0.9090 & 0.9995 \\
& Special cubic & $38.791^{\mathrm{a}}$ & 4.950 & $24.816^{\mathrm{c}}$ & 19.160 & 0.9790 & 0.9995 \\
\hline
\end{tabular}

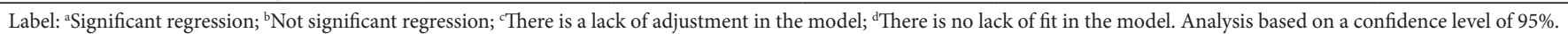

mentioned above, was chosen to represent the variable in question.

The fruity aroma is also an important parameter of must definition. However, as the aroma analysis has no numerical results, it was not possible to add it as a variable on the research, although this characteristic was also taken into account when choosing the ideal formulation.

Analyzing Table 2 data, we can see that no model had lack of fit for the total reducing sugar variable, but just the linear model had significant regression. To the variable total titratable acidity, all models had significant regression and just the quadratic and special cubic models had not had lack of fit. The third order interaction of the special cubic model was very low (0.465), not influencing significantly the model, though. In addition, the residual graphics of these models showed a linear trend, demonstrating that the model is not significant.

To the phenolic compounds variable, all models had a significant regression, but all of them had lack of fit, too. Nevertheless, the especial cubic model had the lowest error among the three models (24.816) and the best explanation of variation percentage ( 97.90 of $99.95 \%$ possible).

After discarding the not significant coefficients, a simplified equation for each property considered was obtained, resulting in a linear model for the total reducing sugars variable (Equation 1), quadratic model for the total titratable acidity (Equation 2) and special cubic model for the phenolic compounds (Equation 3).

$T R S=142.857 \times x_{1}+116.891 \times x_{2}+122.185 \times x_{3}$ 


$$
\begin{aligned}
T T A & =3.589 \times x_{1}+5.517 \times x_{2}+4.697 \times x_{3}+0.222 \times x_{1} \times x_{2} \\
& +0.266 \times x_{1} \times x_{3}+0.222 \times x_{2} \times x_{3} \\
P C= & 377.971 \times x_{1}+344.927 \times x_{2}+209.565 \times x_{3}+32.868 \times x_{1} \times x_{2} \\
& -50.252 \times x_{1} \times x_{3}+89.293 \times x_{2} \times x_{3}+673.591 \times x_{1} \times x_{2} \times x_{3}
\end{aligned}
$$

From the regression models, ternary diagrams of response surfaces were made for each studied variable. Figure 2a shows the total reducing sugar, Figure $2 b$ the total titratable acidity and Figure $2 c$ the phenolic compounds variable.

The highest concentration of total reducing sugar was found in the compositions with the highest levels of the Catarina cultivar, in other words, near the vertex that represents this juice (Figure 2a). This fact that can also be observed in Equation 1, where the highest parameter is the one that represents the proportion of the cultivar Catarina (x1).

To the total titratable acidity variable, the Granny Smith and Pink Lady cultivars contributed to the increase of juice acidity (Figure 2b). In Equation 2, the greatest parameters were those that represented the individual proportions of the cultivars Granny Smith (x2) and Pink Lady (x3), as observed in Figure 2b. Besides, in these models, it is observed that, as all interaction binary coefficients are positive, the binary species interacted synergistically, i.e., the interaction between the juices contributed to increase the acidity.

Figure $2 c$ shows that the higher the Catarina and Granny Smith cultivars proportions, the higher the phenolic compounds content of the blend. In Equation 3, the parameter of interaction between Catarina and Pink Lady cultivars $(\mathrm{x} 1 \times \mathrm{x} 3)$ showed a negative value, demonstrating that the binary interaction contributes to decrease the phenolic compounds content of the blend (antagonistic interaction). Nevertheless, the significant value of the ternary interaction variable $(\mathrm{x} 1 \times \mathrm{x} 2 \times \mathrm{x} 3)$ showed the substantial contribution of the blend to the increase of the phenolic compounds content.

The ideal blend under study must provide the highest possible values in all studied parameters, in conformity with what is necessary for a good sparkling drink. According to Rizzon, Meneguzzo and Gasparin (2005), the must has to show high acidity, high content of phenolic compounds and sugars, plus a highly fruity aroma.

To delimit the minimum values for the studied parameters, the following values were used: minimum of 123.0 g.L. $\mathrm{L}^{-1}$ of total reducing sugar, once this is the quantity of sugar necessary to obtain a $7.0 \% \mathrm{v} / \mathrm{v}$ alcohol wine (considering a conversion of $17.5 \mathrm{gL}^{-1}$ for each alcoholic degree); minimum of 5.0 g.L.- of acidity in malic acid, since Brazilians high quality sparkling drinks have around 75.0 meq. $\mathrm{L}^{-1}$ of total acidity (RIZZON; MENEGUZZO; GASPARIN, 2005); and minimum of $340.0 \mathrm{mg} . \mathrm{L}^{-1}$ of phenolic compounds, where the value was defined by the conditions established at the charts intersection.

With the boundaries, a viable region was demarcated (gray region in Figure 3) representing an intersection area between all variables, where it is possible to find minimum and maximum proportions for each used juice, so that all variables have values within the pre-established standards. From this region, a central

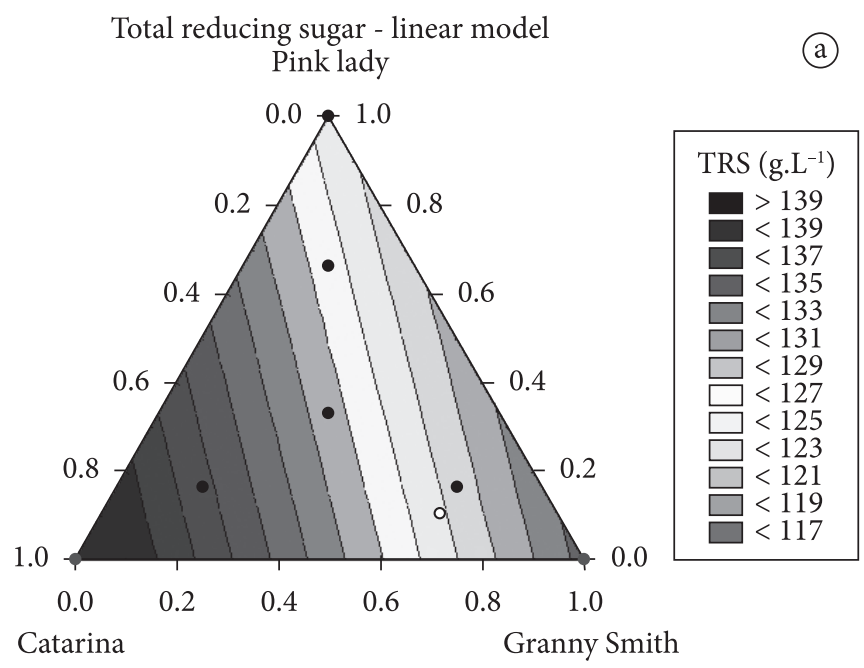

Total titratable acidity - quandratic model Pink lady

(b)

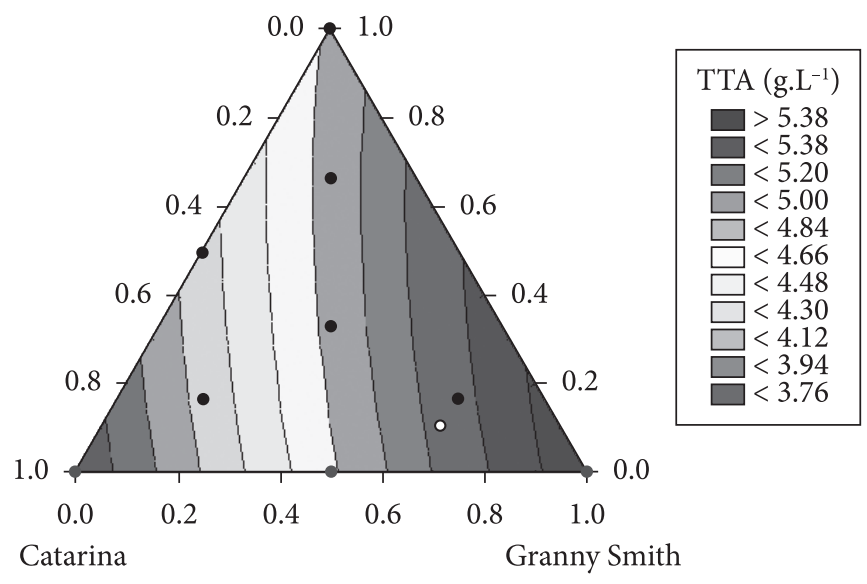

Phenolic compounds - special cubic model Pink lady

(c)

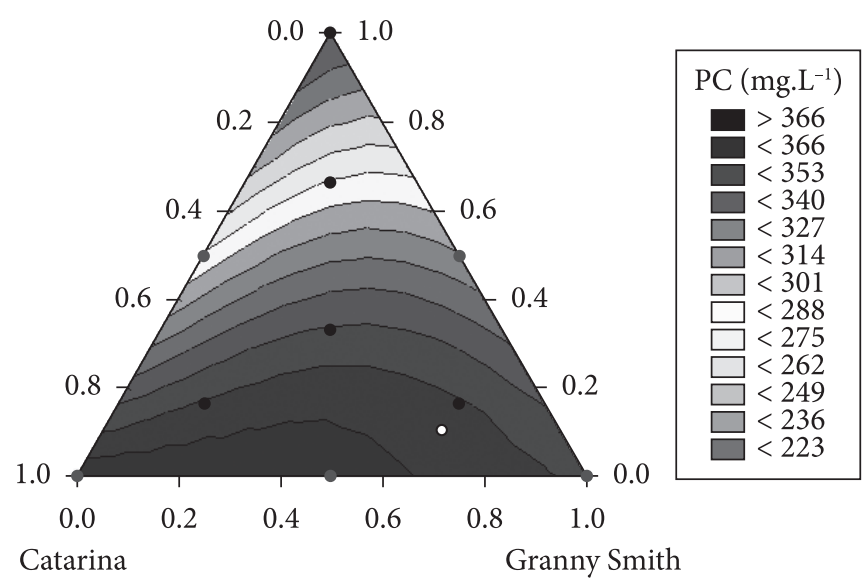

Figure 2. Response surfaces ternary diagrams concerning the variables: a) TRS; b) TTA; c) PC. Label: TRS - total reducing sugar (10 g. $\left.\mathrm{L}^{-1}\right)$; b) TTA - total titratable acidity (g. $\mathrm{L}^{-1}$ malic acidity); c) PC - phenolic compounds $\left(10^{2} \mathrm{mg} . \mathrm{L}^{-1}\right)$. The points represents: the necessary assays to the elaboration of the models (blue), the assays used to test the models quality (black) and the intersection point between the respond surface (gray). 


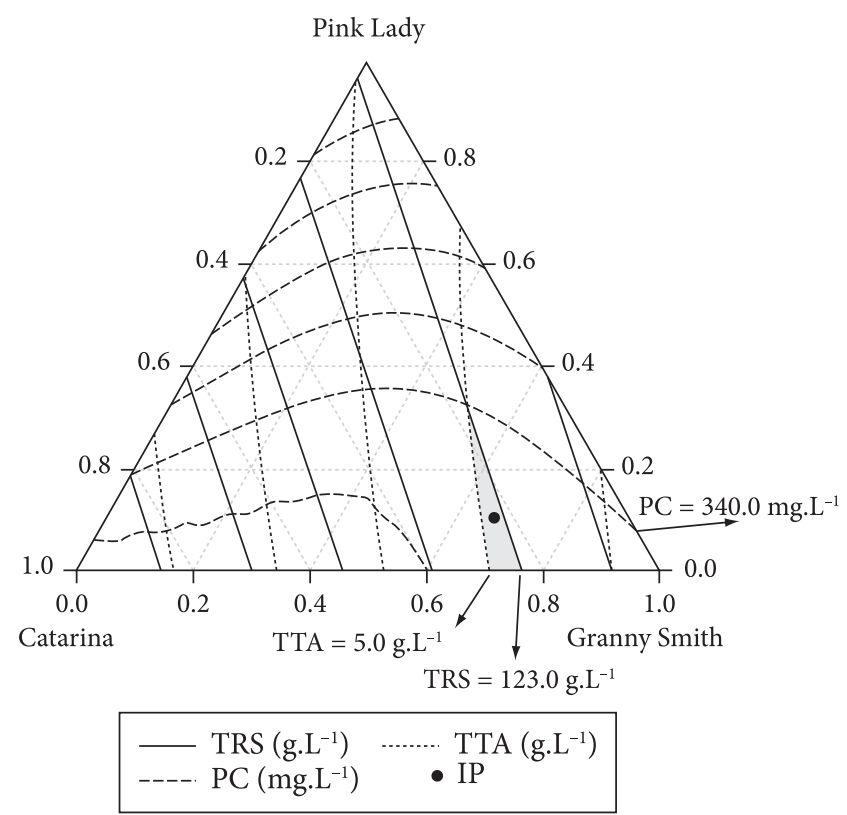

Figure 3. Ternary interaction diagram of the response surface to total reducing sugar (TRS), total titratable acidity (TTA) and phenolic compounds (PC), where the blue point represent the intersection point (IP).

point was calculated (identified as IP - intersection point), being this point just one of all possible compositions that satisfy the restrictions.

Analyzing the viable region, it is observed that to satisfy the restrictions: i) the Catarina cultivar must be used in a maximum of $29.19 \%$ and, in this case, the Granny Smith cultivar must be used in $70.81 \%$ and the Pink Lady in $0.00 \%$; ii) the Granny Smith cultivar must be used in a maximum of $76.47 \%$ and, in this case, the cultivar Catarina must be used in $23.54 \%$ and the Pink Lady in $0.00 \%$; iii) the Pink Lady cultivar must be used in a maximum of $31.66 \%$ and, in this case, the Catarina cultivar must be used in $16.94 \%$ and the Granny Smith in $51.40 \%$. These three points refer to the three vertexes of the triangle that represents the viable region.

The intersection point (IP) represented by the blue point on Figure 3, represents the percentages $23.22 \%$ of Catarina cultivar, $66.23 \%$ of Granny Smith cultivar and $10.55 \%$ of Pink Lady cultivar and it was chosen to represent the results, i.e., these proportions was chosen to, subsequently, make the must to be submitted to fermentation process. According to the obtained models, the juice made with these proportions should have the following characteristics: 123.48 g. $\mathrm{L}^{-1}$ of total reducing sugar, 5.04 g. $\mathrm{L}^{-1}$ of total titratable acidity and $359.31 \mathrm{mg} . \mathrm{L}^{-1}$ of phenolic compounds, values that satisfy the established restrictions in this work for sparkling drink preparation. The usage of this point is justified because it is within the specified limits of the viable region and because it is a central point of this area.

Paganini et al. (2004) and Wosiacki, Pholman and Nogueira (2004) analyzed six and fifteen apple cultivars, respectively, and according to those studies, the cultivars presented average values of 132.3 and $117.8 \mathrm{~g} . \mathrm{L}^{-1}$ of total reducing sugar, 3.3 and $3.6 \mathrm{~g} . \mathrm{L}^{-1}$ of total titratable acidity and 340.0 and $316.0 \mathrm{mg} \cdot \mathrm{L}^{-1}$ of phenolic compounds, respectively.

Based on these results, one can verify that the total reducing sugar value of the must made with the blend it is within the values presented by the authors. The blend acidity proved to be considerably above the indicated average, what is a positive point of the blend, since the intention was to obtain a must with high acidity. Regarding to the phenolic compounds content, it is believed that the use of a cultivar with more significant values of this variable in the formulation of the blend, would make the must more interesting; once, according to Rizzon, Meneguzzo and Gasparin (2005), for the elaboration of a quality sparkling drink, a must with high content of phenolic compounds is necessary, and the value obtained for this variable was very close to the values found by the authors.

\section{Conclusions}

The application of the components blend design, allied to the response surface methodology, allowed to define a range of apple juice compositions that make a must able to be employed in the sparkling apple drink preparation.

To the studied situation and according to the established models, the proportion of the blends that provides the physical-chemical characteristics more suited to the sparkling development, i.e., a must that holds high values for the properties total reducing sugars, total titratable acidity and phenolic compounds and has fruity aroma, should be composed, on average, by the following blend: $23.22 \%$ of the cultivar Catarina, $66.23 \%$ of the cultivar Granny Smith and $10.55 \%$ of the cultivar Pink Lady, being this the central point among the many combinations that satisfy the pre-set restrictions.

To obtain a must with more specific characteristics, like a high content of phenolic compounds, for example, it would be interesting to use another apple cultivar that has more expressive value of this characteristic. In this case, however, all the design must be performed again.

\section{Acknowledgements}

The authors would like to thank the 'Universidade Estadual de Ponta Grossa' for the support and the 'Agrícola Fraiburgo Ltda' for the yielded infrastructure and for the grants supplied for the development of this research.

\section{References}

BARROS NETO, B.; SCARMINIO, I. S.; BRUNS, R. E. Como fazer experimentos: pesquisa e desenvolvimento na ciência e na indústria. 3. ed. Campinas: Unicamp, 2007. 480 p.

BRUNS, R. E.; SCARMINIO, I. S.; BARROS NETO, B. Como fazer experimentos: pesquisa e desenvolvimento na ciência e na indústria. Campinas: Unicamp, 2001.

INSTITUTO ADOLFO LUTZ - IAL. Métodos físicos e químicos para análise de alimentos. In: IAL. Normas analíticas. 4. ed. São Paulo: Instituto Adolfo Lutz, 2008. 1020 p.

JORGE, Z. L. C.; TREPTOW, R. O.; ANTUNES, P. L. Avaliação físicoquímica e sensorial de suco de maçãs cultivares fuji, granny smith e 
seus "blends". Revista Brasileira de Agrociência, v. 4, n. 1, p. 15-19, jan./abr. 1998.

PAGANINI, C. et al. Análise da aptidão industrial de seis cultivares de maçãs, considerando suas avaliações físico-químicas (dados da safra 2001/2002). Ciência Agrotecnológica, Lavras, v. 28, n. 6, p. 1336-1343, nov./dez. 2004.

RIZZON, L. A; MENEGUZZO, J.; GASPARIN, A. M. Elaboração do vinho moscatel espumante. Bento Gonçalves: Embrapa Uva e Vinho, 2005. 42 p.

SINGLETON, V. L.; ORTHOFER, R.; LAMUELA-RAVENTOS, R. M. Analysis of total phenols and other oxidation substrates and antioxidants by means of Folin-Ciocalteu reagent. Methods in Enzymology, v. 299, p. 178-184, 1999.
TANNER, H.; BRUNNER, H. R. Getränke anlytik: untersuchungsmethode für dia Labor und Betriebspraxis. Wädesnwill: Verlag Helles, 1985. 206 p.

WOSIACKI, G. Apple varieties growing in subtropical areas: the situation in Santa Catarina - Brazil. Fruit Processing, Schönborn, v. 12, n. 1, p. 19-28, jan. 2002.

WOSIACKI, G.; NOGUEIRA, A. Suco de maçã. In: FILHO, W. G. V. (Org.). Tecnologia de bebidas: matéria prima, processamento, BPF/APPCC, legislação e mercado. São Paulo: Edgard Blücher, 2005. cap. 12. p. 255-292.

WOSIACKI, G.; PHOLMAN, B. C.; NOGUEIRA, A. Características de qualidade de cultivares de maçã: avaliação físico-química e sensorial de quinze cultivares. Ciência e Tecnologia de Alimentos. Campinas, v. 24, n. 3, p. 347-352, jul./set. 2004. 